\title{
Studi Karakteristik Briket Tempurung Kelapa dengan Berbagai Jenis Perekat Briket
}

Study of the Characteristics of Coconut Shell Briquette with Various Types of Briquette Adhesives

\author{
Edy Wibowo Kurniawan*, Mujibu Rahman, Rudi Karta Pemuda \\ Program Studi Teknologi Hasil Perkebunan, Politeknik Pertanian Negeri Samarinda, Indonesia \\ ${ }^{*}$ Correspondence Author: edy_wibowosmd@yahoo.com
}

\begin{abstract}
ABSTRAK
Banyak negara di dunia berlomba-lomba mengembangkan sumber energi baru terbarukan seiring berkurangnya cadangan energi bersumber dari fosil.Indonesia juga mengembangkan sumber energi terbarukan ini, salah satunya energi dari biomassa.Briket tempurung kelapa merupakan salah satu pengembangan energi biomassa, namun pengembangan jenis perekat masih terus diteliti. Penelitian ini bertujuan untuk mengetahui karakteristik briket tempurung kelapa dengan berbagai jenis perekat briket. Penelitian dilakukan dengan mengecilkan ukuran arang tempurung kelapa sampai berukuran lolos 40 mesh, kemudian di campur dengan berbagai variasi perekat dengan proporsi $15 \%$. Campuran tepung arang dengan perekat (tapioka, tanah liat, dan bentonit) dibasahi dan dicetak berbentuk silindris kemudian dikeringkan dengan cabinet drier. Setelah kering masing-masing produk dianalisa kadar air, kadar abu, kadar zat volatil, kadar karbon terikat dan nilai kalori dengan metode ASTM D-3175. Kemudian dihitung rerata dan dianalisa sidik ragam serta uji lanjut Duncan. Dari hasil penelitian disimpulkan bahwa briket dengan semua jenis perkat memenuhi standar mutu baik untuk kadar air, kadar abu, kadar karbon terikat dan nilai kalori. Kecuali untuk kadar zat volatil masih belum memenuhi standar. Adapun nilai kalori tertinggi ditunjukkan pada produk briket dengan perlakuan perekat tapioka dengan nilai $6314,46 \mathrm{kal} / \mathrm{g}$.
\end{abstract}

Kata kunci : Briket, Tempurung kelapa, Nilai kalori

\begin{abstract}
A number of countries in the world are competing to develop new renewable energy sources along with the reduction in energy reserves from fossil sources. Indonesia is also developing this renewable energy source, one of which is energy from biomass. Coconut shell briquette is one of the development of biomass energy, but the development of adhesive types is still continuing researched. This research aims to determine the characteristics of coconut shell briquettes with various types of briquette adhesives. The study was conducted by reducing the size of the coconut shell charcoal to pass the size of 40 mesh, then mixed with various adhesive variations with a proportion of $15 \%$. The mixture of charcoal flour with adhesive (tapioca, clay, and bentonite) is moistened and printed in a cylindrical form and then dried with a cabinet drier. After drying each product was analyzed for water content, ash content, volatile matter content, fixed carbon content and calorific value by ASTM D-3175 method. Then the mean was calculated and analyzed for variance and Duncan's test. The results of the research concluded that briquettes with all types of perkat meet quality standards both for water content, ash content, carbon content bound and calorific value. Except for the levels of volatile substances still do not meet the standards. The highest calorie value is shown in briquette products with tapioca adhesive treatment with a value of $6314.46 \mathrm{cal} / \mathrm{g}$.

Keywords : Briquettes, Coconut Shell, Calorie Value
\end{abstract}




\section{PENDAHULUAN}

Pemerintah Indonesia telah mencanangkan pencarian dan penggunaan sumber sumber energi baru dan terbarukan melalui perundang-undangan yang telah ditetapkan bersama DPR. Salah satu sumber energi tersebut adalah energi biomassa,yang merupakan energi alternatif pengganti bahan bakar fosil (minyak bumi) karena beberapa sifatnya yang menguntungkan yaitu dapat dimanfaatkan secara lestari karena sifatnya yang dapat diperbaharui (renewable resources), relatif tidak mengandung sulphur sehingga tidak menyebabkan polusi udara (Arni dkk, 2014).

Negara Indonesia merupakan negara agraris yang sebagian pendapatan penduduknya dengan bercocok tanam. Selain hasil panenan yang akan dikonsumsi, juga sistem ini akan menghasilkan limbah pertanian dan pengolahan hasil pertanian dalam jumlah yang besar. Berbagai jenis limbah dapat diolah menjadi energi biomassa antara lain : limbah kayu, limbah tanaman dan pertanian, limbah olahan hasil pertanian dan lain-lain (Wilk dkk, 2015). Komoditas kelapa menghasilkan berbagai produk utama seperti : santan, minyak kelapa, VCO, kelapa parut dan lain lain. Hasil samping dari pengolahannya brupa limbah antara lain: tempurung kelapa, sabut, ampas dan lain-lain. Oleh karena itu pemanfaatan tempurung kelapa menjadi briket merupakan salah satu alternatif dalam penanganan limbah yang akan diubah menjadi produk untuk pemenuhan energi.

Berbagai jenis perekat dalam pembuatan briket yang dapat dipergunakan seperti : tapioka, tepung ketan, tanah liat, bentonit, tar, dan lain-lain Tempurung kelapa memiliki potensi untuk menjadi briket tempurung kelapa dengan keunggulan dari segi nilai kalor dan kadar air. Namun pemilihan jenis perekat yang tepat akan mempengaruhi kualitas produk briket yang dihasilkan, terutama nilai kalornya. Tujuan penelitian untuk melihat karakteristik briket tempurung kelapa dengan berbagai jenis perekat briket.

\section{METODE PENELITIAN}

\section{Bahan dan Peralatan}

Bahan pada penelitian ini berupa arang tempurung kelapa yang diperoleh dari pasar Harapan Baru, tepung tapioka, tanah liat dan bentonit dari laboratorium Kelapa Sawit Politeknik Pertanian Negeri Samarinda.

Adapun peralatan yang digunakan antara lain: cetakan briket bentuk silindris, seperangkat alat analisa karbon merk Toshniwal, cabinet dryer, peralatan gelas untuk uji proksimat kadar air, kadar abu, kadar zat volatil, kadar karbon terikat, dan nilai kalori.

\section{Pembuatan Arang dan Pengujian}

Arang tempurung kelapa diperkecil ukurannya sampai berukuran lolos 40 mesh, kemudian dicampur dengan berbagai jenis perekat (tapioka, tanah liat, bentonit) sebesar 15\% terhadap arang tempurung untuk masing-masing perekat. Setelah adonan dibasahi dengan sedikit air agar mudah dicetak dan dipres pada alat pencetak briket, kemudian briket dimasukkan dalam pengering cabinet dryer. Setelah briket kering dilakukan analisa kadar air, kadar abu, kadar zat volatil, kadar karbon dan nilai kalori dengan metode ASTM D-3175 (Kurniawan, 2008).

\section{Analisa Data}

Data yang diperolah kemudian dianalisa dengan uji Analysis of Variance (ANOVA) untuk menilai signifikansi perbedaan diantara nilai rata-rata yang didapatkan. Data dengan perbedaan signifikan akan dianalisa dengan uji lanjut 
Duncan. Proses analisa data dilakukan menggunakan software SPSS 16.0.

\section{HASIL DAN PEMBAHASAN}

\section{Kadar Air}

Kadar air merupakan salah satu parameter kualitas dari briket, yang akan mempengaruhi nilai kalor dari briket tersebut. Adapun hasil analisa kadar air pada penelitian seperti terlihat pada Tabel 1.

Tabel 1. Hasil Analisa Kadar Air Pada Briket Tempurung Kelapa.

\begin{tabular}{ccccc}
\hline \multirow{2}{*}{ Perlakuan } & \multicolumn{3}{c}{ Ulangan } & Rata- \\
\cline { 2 - 4 } & 1 & 2 & 3 & rata \\
\hline P1 & 2,49 & 2,57 & 3,1 & $2,72 a$ \\
P2 & 3 & 1,81 & 4,01 & $2,94 a$ \\
P3 & 3,04 & 2,34 & 3,18 & $2,85 a$ \\
\hline
\end{tabular}

Keterangan: $\mathrm{P} 1=$ briket arang tempurung kelapa berperekat tapioka ; P2 = briket arang tempurung kelapa berperekat tanah liat;P3 = briket arang tempurung kelapa berperekat bentonit. Notasi huruf yang sama dalam satu kolom menunjukkan antara perlakuan tidak berbeda nyata melalui uji Duncan.

Berdasarkan Tabel 1., terlihat bahwa masing-masing perlakuan memiliki nilai rerata kadar air rata - rata $2,72 \%$ hingga $2,94 \%$. Kadar air pada briket arang tempurung kelapa sudah memenuhi standar briket Jepang (6-8\%), Inggris (3$6 \%)$, Amerika (6\%) dan Indonesia (8\%)(FAO, 1996).Adapun analisa sidik ragam seperti terlihat pada Tabel 2 .

Tabel 2. Analisa Sidik Ragam Kadar Air Briket Tempurung Kelapa

\begin{tabular}{|c|c|c|c|c|c|}
\hline & $\begin{array}{l}\text { Sum of } \\
\text { Squares }\end{array}$ & df & $\begin{array}{l}\text { Mean } \\
\text { Square }\end{array}$ & $F$ & Sig. \\
\hline $\begin{array}{l}\text { Between } \\
\text { Groups }\end{array}$ & .070 & 2 & .035 & .071 & .932 \\
\hline $\begin{array}{l}\text { Within } \\
\text { Groups }\end{array}$ & 2.981 & 6 & .497 & & \\
\hline Total & 3.051 & 8 & & & \\
\hline
\end{tabular}

Kadar air pada standar briket Indonesia yang baik yakni $<8 \%$ sedangkan pada penelitian ini diketahui kadar air pada briket arang tempurung kelapa adalah berkisar antara 2,72\% hingga 2,94\%. Hal ini menunjukkan bahwa nilai rata-rata kadar air pada setiap perlakuan sudah memenuhi syarat mutu standart SNI yaitu $<8 \%$ (Arni dkk, 2014)

Perekat yang digunakan memberikan perbedaan kadar air yang dihasilkan.Hal ini sesuai dengan penelitian Kong, dkk (2014), bahwa jenis perekat dan persentase perekat memberi pengaruh yang berarti terhadap kadar air yang terkandung dalam briket. Selain itu, bahan baku juga mempengaruhi tingginya kadar air dalam briket dikarenakan strukturnya terdiri dari 6 atom $\mathrm{C}$ yang membentuk kisiheksagonal yang memungkinkan uap air terperangkap didalamnya dan tidak menguap pada kondisi pengeringan dengan oven (Nurmalasari dan Afiah, 2017).

\section{Kadar Abu}

Kadar abu merupakan bagian yang tersisa dari hasil pembakaran, dalam hal ini abu yang dimaksud adalah abu sisa pembakaran briket.Salah satu penyusun abu adalah silika, pengaruhnya kurang baik terhadap nilai kalor briket arang yang dihasilkan.Nilai kadar abu briket pada setiap sampel dapat dilihat pada Tabel 3.dan analisa sidik ragam seperti terlihat pada Tabel 4.

Tabel 3. Hasil Analisa Kadar Abu Pada Briket Tempurung Kelapa

\begin{tabular}{|c|c|c|c|c|}
\hline \multirow{2}{*}{ Perlakuan } & \multicolumn{3}{|c|}{ Ulangan } & \multirow{2}{*}{$\begin{array}{l}\text { Rata- } \\
\text { rata }\end{array}$} \\
\hline & 1 & 2 & 3 & \\
\hline $\mathrm{P} 1$ & 3,11 & 3,79 & 4,41 & $3,77 a$ \\
\hline P2 & 3,42 & 4,9 & 4,32 & $4,21 a$ \\
\hline P3 & 3,26 & 4,6 & 4,49 & $4,12 a$ \\
\hline
\end{tabular}

Keterangan: $\mathrm{P} 1=$ briket arang tempurung kelapa berperekat tapioka; P2 = briket arang tempurung kelapa berperekat tanah liat; P3 = briket arang tempurung kelapa berperekat bentonit. Notasi huruf yang sama dalam satu kolom menunjukkan antara perlakuan tidak berbeda nyata melalui uji Duncan. 
Tabel 4. Analisa Sidik Ragam Kadar Abu Briket Tempurung Kelapa

\begin{tabular}{lccccc}
\hline & $\begin{array}{c}\text { Sum of } \\
\text { Squares }\end{array}$ & df & $\begin{array}{c}\text { Mean } \\
\text { Square }\end{array}$ & F & Sig. \\
\hline $\begin{array}{l}\text { Between } \\
\text { Groups }\end{array}$ & .326 & 2 & .163 & .319 & .738 \\
$\begin{array}{l}\text { Within } \\
\text { Groups }\end{array}$ & 3.065 & 6 & .511 & & \\
Total & 3.391 & 8 & & & \\
\hline
\end{tabular}

Kadar abu yang terdapat dalam briket arang tempurung kelapa disebabkan adanya penambahan abu dari bahan baku dan perekat yang digunakan baik dari tapioka, tanah liat, dan bentonit. Semakin tinggi kadar perekat maka abu yang dihasilkan semakin tinggi pula. Tingginya kadar abu dipengaruhi oleh pengotor yang terkandung dalam bahan baku sehingga kandungan mineral-mineral dalam arang cukup tinggi dan dalam proses pembakarannya banyak meninggalkan abu sebagai sisa pembakaran. Selain itu, tingginya kadar abu dapat pula disebabkan karena adanya pengotor eksternal yang berasal dari lingkungan sekitar pada saat proses pembuatan briket (Ristianingsih,dkk.2015).

Kadar abu briket berpengaruh terhadap nilai kalor. Semakin kecil kadar abu maka semakin tinggi nilai kalornya (Kurniawan, 2010). Sehingga kadar abu dalam pembuatan briket arang diharapkan serendah mungkin supaya nilai kalor briket arang tinggi. Kadar abu terendah pada penelitian ini adalah perlakuan $\mathrm{P} 1$ sebesar $3,77 \%$. Semua hasil kadar abu pada penelitian ini memenuhi persyaratan SNI untuk standar briket arang indonesia yaitu kadar abu maksimal briket arang adalah $<8 \%$ (Arni dkk, 2014).

\section{Kadar Zat Volatil}

Kadar zat menguap adalah zat (volatile matter) yang dapat menguap sebagai dekomposisi senyawa-senyawa yang masih terdapat di dalam arang selain air. Adapun nilai kadar zat volatil terlihat pada Tabel 5, sedangkan hasil analisa sidik ragam terlihat pada Tabel 6 .

Tabel 5. Hasil Analisa Kadar Zat Volatil Pada Briket Tempurung Kelapa

\begin{tabular}{ccccc}
\hline \multirow{3}{*}{ Perlakuan } & \multicolumn{3}{c}{ Ulangan } & $\begin{array}{c}\text { Rata- } \\
\text { rata }\end{array}$ \\
\cline { 2 - 4 } & 1 & 2 & 3 & $43,68 a$ \\
P1 & 6,84 & 80,46 & 43,73 & 43,00 \\
P2 & 34,69 & 34,22 & 33,10 & $34,00 a$ \\
P3 & 34,14 & 34,53 & 35,21 & $34,63 a$ \\
\hline
\end{tabular}

Keterangan: $\mathrm{P} 1=$ briket arang tempurung kelapa berperekat tapioka; P2 = briket arang tempurung kelapa berperekat tanah liat; P3 = briket arang tempurung kelapa berperekat bentonit. Notasi huruf yang sama dalam satu kolom menunjukkan antara perlakuan tidak berbeda nyata melalui uji Duncan.

Tabel 6. Analisa Sidik Ragam Kadar Zat Volatil Briket Tempurung Kelapa

\begin{tabular}{lccccc}
\hline & $\begin{array}{c}\text { Sum of } \\
\text { Squares }\end{array}$ & df & $\begin{array}{c}\text { Mean } \\
\text { Square }\end{array}$ & F & Sig. \\
\hline $\begin{array}{l}\text { Between } \\
\text { Groups }\end{array}$ & 176.708 & 2 & 88.354 & .195 & .827 \\
$\begin{array}{l}\text { Within } \\
\text { Groups }\end{array}$ & 2711.799 & 6 & 451.96 & & \\
Total & 2888.507 & 8 & & & \\
\hline
\end{tabular}

Kadar zat volatil berbeda-beda untuk setiap bahan karena dipengaruhi oleh zatzat mudah menguap yang terkandung dari bahan tersebut.Kandungan kadar zat volatil yang tinggi di dalam briket arang akan menyebabkan asap yang lebih banyak pada saat dinyalakan, apabila $\mathrm{CO}$ bernilai tinggi hal ini tidak baik untuk kesehatan dan lingkungan sekitar (Kurniawan, 2008).

Dari Tabel 5 terlihat bahwa zat mudah menguap tertinggi dimiliki oleh perlakuan $\mathrm{P} 1$ sebesar $43,68 \%$ dan yang terendah perlakuan P2 sebesar $34,00 \%$. Berdasarkan standar kualitas briket arang khususnya untuk zat volatil, terlihat bahwa pada masing-masing negara berbeda standar $15-30 \%$ (Jepang) dan 15\% untuk SNI. Sedangkan pada penelitian ini kadar zat volatil yang dihasilkan yakni $34-44 \%$ sehingga belum memenuhi standar (Arni dkk, 2014). 
Menurut Ristianingsih dkk, (2015), apabila kadar air tinggi akan menghasilkan nilai zat volatil yang tinggi pula. Kadar zat volatil yang tinggi bisa disebabkan karena tidak sempurnanya proses karbonisasi. Disamping itu kadar zat volatil juga dipengaruhi oleh suhu dan waktu pengarangan. semakin besar suhu pada waktu pengarangan sehingga kandungan zat menguap akan semakin kecil. Pada briket arang diharapkan memiliki kadar zat menguap yang serendah mungkin (Nurmalasari dan Afiah, 2017).

\section{Kadar Karbon Terikat}

Karbon terikat menunjukkan jumlah arang yang tersisa setelah tahap devolatilisasi yaitu tahap pembakaran biomassa hingga semua komponen volatil teruapkan.Karbon terikat merupakan persentase karbon yang tersisa dari pembakaran arang (Kurniawan, 2008). Adapun nilai kadar karbon terlihat pada Tabel 7, sedangkan hasil analisa sidik ragam terlihat pada Tabel 8.

Tabel 7. Hasil Analisa Kadar Karbon Terikat Pada Briket Tempurung Kelapa

\begin{tabular}{ccccc}
\hline \multirow{2}{*}{ Perlakuan } & \multicolumn{3}{c}{ Ulangan } & $\begin{array}{c}\text { Rata- } \\
\text { rata }\end{array}$ \\
\cline { 2 - 4 } & 1 & 2 & 3 & $48,43 a$ \\
P1 & 87,56 & 12,38 & 48,35 & $49,43 a$ \\
P2 & 58,85 & 59,68 & 58,86 & $59,13 a$ \\
P3 & 59,22 & 58,07 & 56,85 & $58,05 a$ \\
\hline
\end{tabular}

Keterangan: $\mathrm{P} 1=$ briket arang tempurung kelapa berperekat tapioka; P2 = briket arang tempurung kelapa berperekat tanah liat; P3 = briket arang tempurung kelapa berperekat bentonit. Notasi huruf yang sama dalam satu kolom menunjukkan antara perlakuan tidak berbeda nyata melalui uji Duncan.

Tabel 8. Analisa Sidik Ragam Kadar Karbon Terikat Briket Tempurung Kelapa

\begin{tabular}{lccccc}
\hline & $\begin{array}{c}\text { Sum of } \\
\text { Squares }\end{array}$ & df & $\begin{array}{c}\text { Mean } \\
\text { Square }\end{array}$ & F & Sig. \\
\hline $\begin{array}{l}\text { Between } \\
\text { Groups }\end{array}$ & 169.511 & 2 & 84.755 & .180 & .840 \\
$\begin{array}{l}\text { Within } \\
\text { Groups }\end{array}$ & 2831.029 & 6 & 471.83 & & \\
Total & 3000.539 & 8 & & & \\
\hline
\end{tabular}

Berdasarkan Tabel 5, nilai karbon terikat dalam briket arang tempurung kelapa adalah $(49,43-59,13) \%$. Nilai kadar karbon terikat terendah adalah 49,43\% terdapat pada perlakuan P1, sedangkan nilai karbon terikat tertinggi pada perlakuan P2 sebesar $59,13 \%$. Arang yang baik adalah yang memiliki karbon terikat yang tinggi karena pada proses pembakaran membutuhkan karbon yang bereaksi dengan oksigen untuk menghasilkan kalor (Ristianingsih dkk., 2015). Kadar karbon tetap terendah yang diperoleh dari penelitian ini adalah 49,43\%. Nilai standar kadar karbon terikat untuk Amerika sebesar $58 \%$, sehingga untuk perlakuan P2 dan P3 memenuhi standar. Namun untuk standar SNI sebesar $77 \%$ mengindikasikan bahwa briket pada penelitian ini belum memenuhi persyaratan mutu SNI di Indonesia (Arni dkk, 2014).

\section{Nilai Kalori}

Nilai kalor sangat menentukan kualitas briket yang dihasilkan.Semakin tinggi nilai kalornya maka semakin tinggi juga kualitas briket yang dihasilkan.Nilai kalor perlu diketahui untuk mengetahui nilai panas pembakaran yang dapat dihasilkan oleh briket sebagai bahan bakar.Nilai kalori terlihat pada Tabel 9, sedangkan hasil analisa sidik ragam terlihat pada Tabel 10 .

Tabel 9. Hasil Analisa Nilai Kalori Pada Briket Tempurung Kelapa $(\mathrm{Kal} / \mathrm{g})$

\begin{tabular}{ccccc}
\hline \multirow{2}{*}{$\begin{array}{c}\text { Perla } \\
\text { kuan }\end{array}$} & \multicolumn{3}{c}{ Ulangan } & $\begin{array}{c}\text { Rata- } \\
\text { rata }\end{array}$ \\
\cline { 2 - 4 } & 1 & 2 & 3 & \\
\hline P1 & 6675,54 & 5765,41 & 6502,44 & $6314,46 a$ \\
P2 & 5387,28 & 5254,89 & 5712,52 & $5451,56 b$ \\
P3 & 5015,86 & 4957,98 & 5558,63 & $5177,49 b$ \\
\hline
\end{tabular}

Keterangan: $\mathrm{P} 1=$ briket arang tempurung kelapa berperekat tapioka; P2 = briket arang tempurung kelapa berperekat tanah liat; P3 = briket arang tempurung kelapa berperekat bentonit. Notasi huruf yang sama dalam satu kolom menunjukkan antara perlakuan tidak berbeda nyata, sedangkan notasi huruf berbeda menunjukkan perlakuan berbeda nyata melalui uji Duncan. 
Tabel 10. Analisa Sidik Ragam Nilai Kalori Briket Tempurung Kelapa

\begin{tabular}{lccccc}
\hline & Sum of Squares & df & Mean Square & F & Sig. \\
\hline Between Groups & 2112420.963 & 2 & 1056210.481 & $7.945^{*}$ & .021 \\
Within Groups & 797658.875 & 6 & 132943.146 & & \\
Total & 2910079.837 & 8 & & & \\
\hline
\end{tabular}

Ket $={ }^{*}$ Perlakuan menunjukkan pengaruh yang berbeda nyata

Berdasarkan dari penelitian yang dilakukan didapatkan hasil nilai kalor tertinggi pada perlakuan $\mathrm{P} 1$ sebesar $6314,46 \mathrm{kal} / \mathrm{g}$ sedangkan yang terendah dari penelitian ini yang diperoleh nilai kalornya adalah perlakuan P3 sebesar $5177,49 \mathrm{kal} / \mathrm{g}$.

Briket yang baik adalah memiliki nilai kalor yang tinggi. Nilai kalor terendah dari penelitian ini adalah $5177,49 \mathrm{kal} / \mathrm{g}$. Nilai kalor ini menunjukkan bahwa nilai kalor briket arang tempurung kelapa ini sudah memenuhi standar nasional Indonesia (SNI) yaitu nilai kalornya minimal dalam briket arang adalah $5000 \mathrm{kal} / \mathrm{g}$ (Kurniawan dkk, 2017).

Nilai kalori briket tercermin dari kadar karbon terikat pada produk. Sebagai bahan bakar karbon terikat yang akan mengalami perubahan bentuk menjadi karbondioksida dengan melepas sejumlah energi. Kadar karbon terikat dari arang maupun briket arang berkisar $50-95 \%$ (FAO, 1996).

\section{KESIMPULAN}

Produk briket dengan berbagai jenis perekat memenuhi standar mutu baik untuk kadar air, kadar abu, kadar karbon terikat dan nilai kalori. Kecuali untuk kadar zat volatil masih belum memenuhi standar. Adapun nilai kalori tertinggi ditunjukkan pada produk briket dengan perlakuan perekat tapioka dengan nilai $6314,46 \mathrm{kal} / \mathrm{g}$

\section{DAFTAR PUSTAKA}

Arni, A., Labania, H. M., \& Nismayanti, A. (2014).Studi Uji Karakteristik Fisis
Briket Bioarang Sebagai Sumber Energi Alternatif. Natural Science: Journal of Science and Technology, 3(1).

FAO, 1996.Biomass Briquetting: Technology And Practices ; FAO Regional Wood Energy Development Programme in Asia, Bangkok, Thailand.

www.fao.org/docrep/006/ad579e lad579e00.pdf

Kong, S.H., Soh-Kheang Loh , Robert Thomas Bachmann, Jumat Salimon Sahibin Abdul Rahim. 2014. Bio Char From Oil Palm Biomass : A Review Of Its Potential And Challenges; Renewable and Sustainable Energy Reviews 39 (2014) 729-739.

Kurniawan, E. W. (2008). Optimasi Produksi White Charcoal Dari Arang Limbah Cangkang Kelapa Sawit (Doctoral dissertation, Universitas Gadjah Mada).

Kurniawan, 2010.Studi Suhu dan Waktu Yang Optimal Pada Produksi Arang Putih Dari Arang Limbah Cangkang Kelapa Sawit, Prosiding Seminar Nasional Nasional (ISBN -.978-602-95436-36), 2010.

Kurniawan, E. W., Amirta, R., Budiarso, E., \& Arung, E. T. (2017, June). Mixing Of Acacia Bark And Palm Shells To Increase Caloric Value Of Palm Shells White Charcoal Briquette. In AIP Conference Proceedings (Vol. 1854, No. 1, p. 020021).AIP Publishing.

Nurmalasari, N., dan Afiah, N. (2017).Briket Kulit Batang Sagu (Metroxylon sagu) Menggunakan Perekat Tapioka Dan Ekstrak Daun Kapuk (Ceiba 
pentandra). Journal of Mathematics and Natural Sciences, 8(1), 1-10.

Ristianingsih Y, Ulfa., A, K.S Rahmi Syafitri, 2015. Pengaruh Suhu Dan Konsentrasi Perekat Terhadap Karakteristik Briket Bioarang Berbahan Baku Tandan Kosong Kelapa Sawit Dengan Proses Pirolisis. Jurnal Konversi. Vol 4, No. 2.

Wilk, M., Magdziarz, A., Kalemba, I., \& Gara, P. (2016).Carbonisation of wood residue into charcoal during low temperature process. Renewable Energy, 85, 507-513. 